\title{
Application of Statistically Based Experimental Designs to Optimize Cellulase Production and Identification of Gene
}

\author{
Aarti Thakkar - Meenu Saraf
}

Received: 10 September 2014/ Accepted: 11 November 2014/Published online: 23 November 2014

(C) The Author(s) 2014. This article is published with open access at Springerlink.com

\begin{abstract}
A natural bacterial strain identified as Bacillus amyloliquefaciens MBAA3 using 16S rDNA partial genome sequencing has been studied for optimization of cellulase production. Statistical screening of media components for production of cellulase by $B$. amyloliquefaciens MBAA3 was carried out by Plackett-Burman design. Plackett-Burman design showed $\mathrm{CMC}, \mathrm{MgSO}_{4}$ and $\mathrm{pH}$ as significant components influencing the cellulase production from the media components screened by Plackett-Burman fractional factorial design. The optimum concentrations of these significant parameters were determined employing the response surface central composite design, involving three factors and five levels was adopted to acquire the best medium for the production of cellulase enzyme revealed concentration of CMC (1.84 g), $\mathrm{MgSO}_{4}(0.275 \mathrm{~g})$, and $\mathrm{pH}$ (8.5) in media for highest enzyme production. Response surface counter plots revealed that middle level of $\mathrm{MgSO}_{4}$ and middle level of $\mathrm{CMC}$, higher level of $\mathrm{CMC}$ and lower level of $\mathrm{pH}$ and higher level of $\mathrm{MgSO}_{4}$ with lower level of $\mathrm{pH}$ increase the production of cellulase. After optimization cellulase activity increased by 6.81 fold. Presence of cellulase gene in MBAA3 was conformed by the amplification of genomic DNA of MBAA3. A PCR product of cellulase gene of $1500 \mathrm{bp}$ was successfully amplified. The amplified gene was conformed by sequencing the amplified product and sequence was deposited in the gene bank under the accession number KF929416.
\end{abstract}

Keywords Bacillus amyloliquefaciens $\cdot$ Cellulase gene $\cdot$ Optimization $\cdot$ Plackett-Burman design $\cdot$ Response surface methodology

\section{Introduction}

Cellulases (1,4-(1,3;1,4)- $\beta$-D-glucan 4-glucanohydrolase) refers to a group of enzymes which hydrolyze cellulose. Cellulose is the most abundant organic source of food, fuel and chemicals [1]. It is the primary product of photosynthesis in terrestrial environments and the most abundant renewable bioresource produced in the biosphere [2]. Cellulase is an enzyme system that consists of at least three different components, i.e. (i) endoglucanase or 1,4- $\beta$-Dglucan-4-glucanohydrolases (EC 3.2.1.4) (ii) exoglucanases

A. Thakkar · M. Saraf $(\bowtie)$

Department of Microbiology, University School of Science, Gujarat University, Ahmedabad 380 009, Gujarat, India

e-mail: sarafmeenu@gmail.com including 1,4- $\beta$-D-glucan glucanohydrolases (cellodextrinases; EC 3.2.1.74) and 1,4- $\beta$-D-glucan cellobiohydrolases (cellobiohydrolases; EC 3.2.1.91), and (iii) $\beta$-glucosidases or $\beta$-glucoside glucohydrolases (EC 3.2.1.21) [3]. Although cellulases are distributed throughout the biosphere, they are mostly found in microbial sources. Cellulases are inducible enzymes synthesized by a large diversity of microorganisms including both fungi and bacteria during their growth on cellulosic materials [1]. Bacteria which have high growth rate as compared to fungi have good potential to be used in cellulase production. The cellulolytic property of some bacterial genera such as Cellulomonas, Cellvibrio, Pseudomonas sp, Bacillus, and Micrococcus has been also reported. Enzyme production is closely controlled in microorganisms and for improving its productivity these controls can be ameliorated. Cellulase yields appear to depend upon a 
complex relationship involving a variety of factors like inoculums size, $\mathrm{pH}$ value, temperature, presence of inducers, medium additives, aeration, growth time, and so forth [4].

Microbial cellulases have potential application in various industries including pulp and paper, textile, laundry, biofuel production, food and feed industry, brewing and agriculture, they are used in animal feeds for improving the nutritional quality and digestibility. A potential challenging area where cellulases would have a central role is the bioconversion of renewable cellulosic biomass to commodity chemicals [5]. Productivity of microbial enzymes and metabolites can be increased by manipulating nutritional requirements, physical parameters and genetic make up of the producing strain. Production cost is considered the bottleneck of many biotechnological processes [6]. Development of economical medium requires selection of carbon, nitrogen, phosphorous, potassium and trace element sources. Nutritional requirement can be manipulated by the conventional or statistical methods. Conventional method involves changing one independent variable at a time while keeping the others at fixed level. However, statistical method offers several advantages over conventional method being rapid and reliable, short lists significant nutrients, helps understanding the interactions among the nutrients at various concentrations and reduces the total number of experiments tremendously resulting in saving time, glassware, chemicals and manpower [7]. Initial screening of the ingredients is done to understand the significance of their effect on the product formation and then a few better ingredients are selected for further optimization [8]. Response surface methodology (RSM) is a useful tool which integrates mathematical and statistical approaches to analyze the effects of defined independent variables on the response without the need for prior knowledge of a predetermined relationship between the response function and the variables [9]. RSM is now considered as a standard statistical approach designing experiments, building models, evaluating the effects of many factors and finding the optimal conditions for desirable responses and reducing the number of required experiments [10]. In the present study, media components such as $\mathrm{CMC}, \mathrm{MgSO}_{4}$ peptone, $\mathrm{pH}$ etc. were evaluated by Plackett-Burman design and further optimized using RSM for increasing cellulase production from our isolate $B$. amyloliquefaciens MBAA3. The role of each variable, their interactions and statistical analysis for cellulase production were explained by applying the second-order polynomial model. The analysis was done using software Design-Expert version 8.0. Further, this study describes the identification of gene encoding for this enzyme and the determination of its nucleotide sequence.

\section{Results and Discussions}

\subsection{Isolation and Identification}

Bacterial culture isolated from farm soil samples collected from Ahmedabad, Gujarat, India on N. agar (Himedia, Mumbai, India) was screened for cellulase production on CMC agar plate. Genomic DNA of the isolate was extracted and the 16S rDNA gene was amplified using universal primers. The purified PCR product was sequenced and the phylogenic relationship of the isolate was determine by comparing the sequence data with the existing sequences available through the gene bank database of the National Center for Biotechnology Information (NCBI, Bethesda, MD, USA) and identified as Bacillus amyloliquefaciens denoted as MBAA3 and the sequence was submitted in the gene bank under the accession number KF535140. The phylogenetic tree as shown in Fig. 1 was drawn using bioinformatics software MEGA 4.0.

\subsection{Statistical Optimization of Cellulase Production from MBAA3}

The chemical composition of the culture medium and environmental factors influence cell growth and cellulase production [6]. A better understanding of the medium components and environmental factors and their optimal control can, therefore, be used to improve the cellulase enzyme production. A statistical method was applied for studying different factors affecting cellulase production by B. amyloliquefaciens isolate MBAA3. Plackett-Burman design was used to screen eight different medium components as 12 run experiment with two level of concentration of each variable The independent variables and their respective high and low concentrations used in the optimization study are represented in Table 1 , whereas the Plackett-Burman experimental design for 12 trials with two level of concentration of each variable is given in Table 2, which was followed for the optimization of medium components for cellulase production. The variables A-H represented the medium constituents and I-K represented the dummy variables/unassigned variables. The results of Plackett-Burman experiment with respect to cellulase production, the effect, standard error, $\mathrm{t}$ (xi), $\mathrm{p}$, and confidence level of each component are represented in Table 5. The components were screened at a confidence level of $95 \%$ on the basis of their effects. When components show significance at or above $95 \%$ confidence level and it's effect is negative, it is considered effective for production but the amount required may be lower than the indicated as low $(-1)$ concentration in Plackett-Burman experiment. If the effect is found positive, a higher concentration than the indicated high value $(+)$ concentration is required. In our 


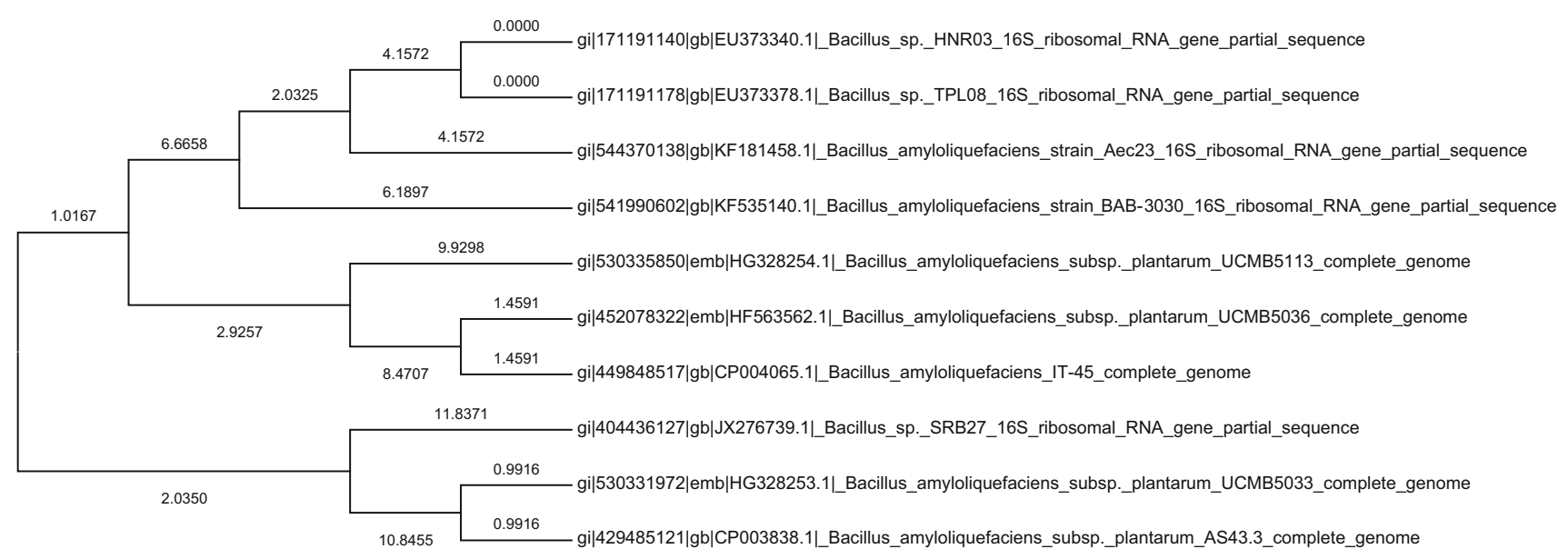

Fig. 1 Phylogenetic relationship on the basis of homology index for bacterial isolate B. amyloliquefaciens MBAA3

Table 1 Medium components and their variables used in PlacketBurman design for cellulase production using Bacillus amyloliquefaciens strain MBAA3

\begin{tabular}{llll}
\hline Variable & Medium component & +Value & -Value \\
\hline A & CMC & 1.0 & 0.1 \\
B & Sucrose & 0.2 & 0.02 \\
C & Yeast extract & 0.2 & 0.02 \\
D & peptone & 0.5 & 0.05 \\
E & $\mathrm{K}_{2} \mathrm{HPO}_{4}$ & 0.1 & 0.01 \\
F & $\mathrm{MgSO}_{4}$ & 0.1 & 0.01 \\
$\mathrm{G}$ & $\mathrm{Temp}$ & 37 & 28 \\
$\mathrm{H}$ & $\mathrm{pH}$ & 5 & 9 \\
\hline
\end{tabular}

Table 2 Plackett-Bueman design generated by fractional rotation of full factorial design where $\mathrm{A}$ to $\mathrm{H}$ is independent variable and $\mathrm{I}$ to $\mathrm{K}$ is dummy variables

\begin{tabular}{llllllllllllr}
\hline Run & A & B & C & D & E & F & G & H & I & J & K & U/mL \\
\hline 1 & + & + & - & + & + & + & - & - & - & + & - & 30.54 \\
2 & - & + & + & - & + & + & + & - & - & - & + & 1.53 \\
3 & + & - & + & + & - & + & + & + & - & - & - & 46.65 \\
4 & - & + & - & + & + & - & + & + & + & - & - & 4.02 \\
5 & - & - & + & - & + & + & - & + & + & + & - & 37.41 \\
6 & - & - & - & + & - & + & + & - & + & + & + & 5.23 \\
7 & + & - & - & - & + & - & + & + & - & + & + & 25.21 \\
8 & + & + & - & - & - & + & - & + & + & - & + & 45.62 \\
9 & + & + & + & - & - & - & + & - & + & + & - & 1.23 \\
10 & - & + & + & + & - & - & - & + & - & + & + & 1.65 \\
11 & + & - & + & + & + & - & - & - & + & - & + & 14.78 \\
12 & - & - & - & - & - & - & - & - & - & - & - & 9.25 \\
\hline
\end{tabular}

experiment $\mathrm{CMC}, \mathrm{MgSO}_{4}$ and $\mathrm{pH}$ gave confidence level $>95 \%$ and could be considered significant. Remaining components as sucrose, yeast extract, peptone, $\mathrm{K}_{2} \mathrm{HPO}_{4}$, and temperature showed confidence level $<95 \%$ and were considered insignificant in the study. The t-value and probability value ( $p$ value) is a tool for evaluating the significance and contribution of each of the parameters to the statistical polynomial model equation. The pattern of interactions between the variables is indicated by these coefficients. The larger the magnitude of $t$ test and the smaller the p-value are an indication of high significance of the corresponding coefficient [11]. Variables with very low probability levels (close to 0.00 ) contribute to the model, while others can be neglected and eliminated from the model. The p-value suggested that the coefficient for the linear effect of $\mathrm{CMC}, \mathrm{MgSO}_{4}$ and $\mathrm{pH}$ were most significant.

The central composite design (CCD) was employed to study the interaction among the significant factors and also determine their optimal levels. In the present work, experiments were planned to obtain a quadratic model consisting of 20 trials. The plan includes 20 experiments and two levels of concentration for each factor. In order to study the combined effect of these variables, experiments were performed at different combinations. The central composite experimental plan along with the predicted and observed response for each individual experiment is summarized in Table 6. It shows the production of cellulase $(\mathrm{U} / \mathrm{ml})$ corresponding to combined effect of all three components in the specified ranges. The production of cellulase may be best predicted by the following model:

$$
\begin{aligned}
\text { Cellulase }= & (27.32)+(1.28 \mathrm{~A})+(0.86 \mathrm{~B})-(2.27 \mathrm{C}) \\
& -(0.85 \mathrm{AB})+(0.98 \mathrm{AC})-(0.006 \mathrm{BC}) \\
& -(0.41 \mathrm{~A} 2)-(1.94 \mathrm{~B} 2)-(1.33 \mathrm{C} 2)
\end{aligned}
$$

where, $\mathrm{Y}$ is cellulase production $(\mathrm{U} / \mathrm{mL})$; $\mathrm{A}$ is CMC concentration (g \%); $\mathrm{B}$ is $\mathrm{MgSO} 4$ (g \%); $\mathrm{C}$ is $\mathrm{pH}$ concentration.

The statistical significance of the second-order polynomial equation was evaluated by F-test ANOVA which revealed that this regression is statistically highly 
significant for cellulase production. The model F-value of 3.79 implies that the model is significant. There is only a $2.47 \%$ chance that a large 'model F-value' could occur due to noise. Values of 'prob $>$ F' less than 0.050 indicate that the model terms are significant (Table 7). The 'lackof-fit F-value' of 1.08 implies the lack of fit is not significant relative to the pure error. There is $46.72 \%$ chance that a large 'lack-of-fit F-value' could occur due to noise. Non-significant lack of fit is good for the model to fit. The R2 value (multiple correlation coefficient) closer to 1 denotes better correlation between observed and predicted values. The coefficient of variation (CV) indicates the degree of precision with which the experiments are compared. The lower reliability of the experiment is usually indicated by high value of $\mathrm{CV}$. In the present case a low CV (9.51) denotes that the experiments performed are reliable. Adequate precision measures the signal to noise ratio. A ratio greater than 4 is desirable. In our case, the ratio is of 6.553 , which indicates an adequate signal. This model can be used to navigate the design space. The effect of interaction of variables on enzyme (cellulase production) yield was studied against any two independent variables while keeping the other independent variables at their constant level. These response surface plots or contour plots can be used to predict the optimal values for different test variables. Therefore, three response surfaces were obtained by considering all the possible combinations. Three-dimensional response plot shown in Fig. 2a describes the behavior of cellulase production, main effect, interaction effect, and squared effect (nonlinear) of $\mathrm{MgSO}_{4}$ and $\mathrm{pH}$ at different concentrations. The shape of the response surface curves showed a moderate interaction between these tested variables. As observed in the contour plot, the middle level of $\mathrm{MgSO}_{4}$ and middle level of $\mathrm{CMC}$ resulted in higher enzyme production. It has been reported that CMC shows inducing effect on cellulase production. Biosynthesis of cellulases in Trichoderma reese $i$ was very high in medium with carboxymethylcellulose as carbon source [12]. The three-dimensional curve and contour plot of the calculated response surface from the interaction between $\mathrm{CMC}$ and $\mathrm{pH}$ while keeping fixed concentration of $\mathrm{MgSO}_{4}$ are shown in Fig. 2b. Both components at their lower level did not result in the higher enzyme yield while $\mathrm{CMC}$ at the higher level and $\mathrm{pH}$ at their lower level showed the maximum enzyme activity. Li et al. [13] also reported the importance of the substrate concentration for xylanse production by Aspergillus awamori. These facts might be accounted for by the report that the enzymes involved in substrate degradation were generally inducible and were formed only when the corresponding substrate was present in the nutrient solution. The interaction plot of $\mathrm{MgSO}_{4}$ and $\mathrm{pH}$ is shown in Fig. 2c, where the shape of the response surface indicates the interaction of $\mathrm{MgSO}_{4}$ and $\mathrm{pH}$ with the fixed coded value of CMC. An increasing $\mathrm{MgSO}_{4}$ with simultaneous decrease in $\mathrm{pH}$ let to increase in cellulase. The enzyme yield was found to increase with higher level of $\mathrm{MgSO}_{4}$ with lower level of $\mathrm{pH}$. Cui and Zhao [14] reported the xylanase production could achieve a higher activity than $44 \mathrm{U} / \mathrm{mL}$ when the concentration of $\mathrm{MgSO}_{4}$ was at a higher level between -0.3 and 0.1 (coded value). It is possible that $\mathrm{Mg}^{2+}$ has a positive effect on the stabilization of the ribosome and cellular membranes and $\mathrm{Ca}^{2+}$ plays a protector role in the medium, which relatively enhances the activity of xylanase. Some researchers have suggested the importance of $\mathrm{Mg}^{2+}$ as a trace element for xylanase production by Aspergillus fischeri Fxn 1 and by Streptomyces olivaceoviridis E-86, and other researchers found that $\mathrm{Mg}^{2+}$ combined with $\mathrm{Fe}^{2+}$ played an important part in xylanase production by Streptomyces sp. QG-11-3, and that $\mathrm{Zn}^{2+}, \mathrm{Mg}^{2+}$ combining with $\mathrm{Fe}^{2+}$ could stimulate the yield of xylanase by Streptomyces thermodiasticus. RSM has been employed for the production of lactic acid from wheat bran by using Lactobacillus amylophilus GV6 [15, 16]. It has also been applied for the production of various enzymes, such as cyclodextrin glucanotransferase (CGTase) [17], chitinase [18], $\alpha$-amylase [19], pectinase [20], Lipase [21] and vitamin riboflavin [22]. RSM can also be useful in optimizing the enzyme reaction conditions. A second order polynomial equation was found to be useful for the development of efficient bioprocess for cellulase production. Second-order polynomial models were used to correlate the abovementioned factors to soluble periplasmic IFN- $\alpha 2 b$ formation and percentage of soluble IFN- $\alpha 2 b$ translocated to the periplasmic space of E. coli and the models were found to be significant and subsequently validated [23]. Statistical optimization of fermentation conditions were reported to enhanced the cellulase production to $2995.20 \pm 200.00 \mathrm{IU} / \mathrm{mL}$, which was 9.91 -fold higher than the activity under unoptimized basal medium (302.2 IU/mL) [24]. The biosynthesis of cellulases in Trichoderma reesei was very high in medium with carboxymethylcellulose as carbon source [12]. Similarly maximum amount of chitinase $(3.47 \mathrm{U} / \mathrm{mL})$ was produced by Basidiobolus ranarum with $1.5 \%$ colloidal chitin, $0.125 \%$ lactose, $0.025 \%$ malt extract and $0.075 \%$ peptone [25]. Li et al. [26] reported maximum cellulase activity $(0.26 \mathrm{U} / \mathrm{mL})$ of a Bacillus sp. When the culture was grown in LB medium supplemented with $1 \% \mathrm{CMC}$. It has been reported recently that Bacillus sp. (DUSELR13) and Brevibacillus sp. (DUSELG12) isolated from gold mine produced maximum CMCase activity 0.12 and 0.02 $\mathrm{U} / \mathrm{mL}$, respectively, under unoptimized conditions [27]. However Cellulase enzyme from B. subtilis (AS3) had an optimum $\mathrm{pH}$ of 9.2 so it was called alkaline cellulase [1]. Considering this property of our enzyme (which is alkaline 


\section{a}

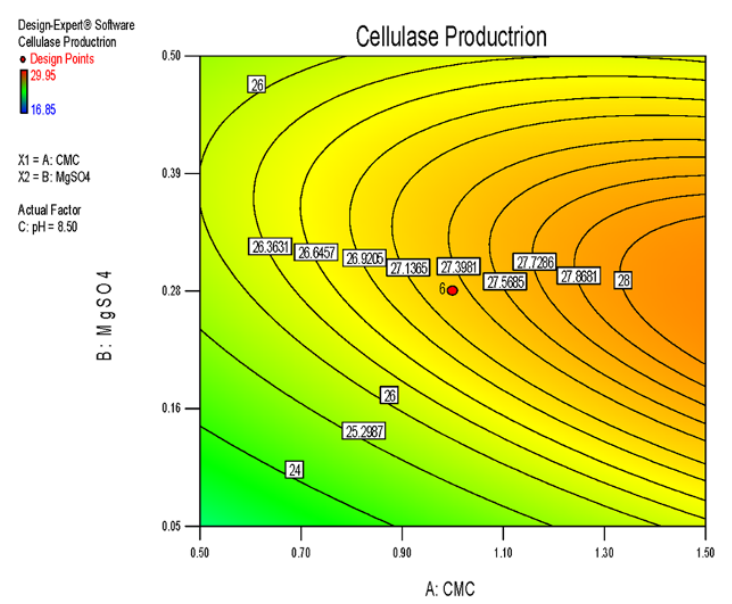

b

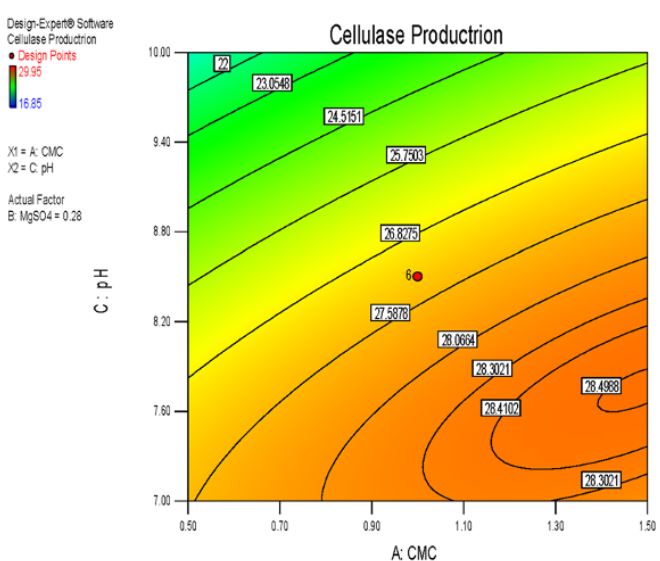

\section{c}

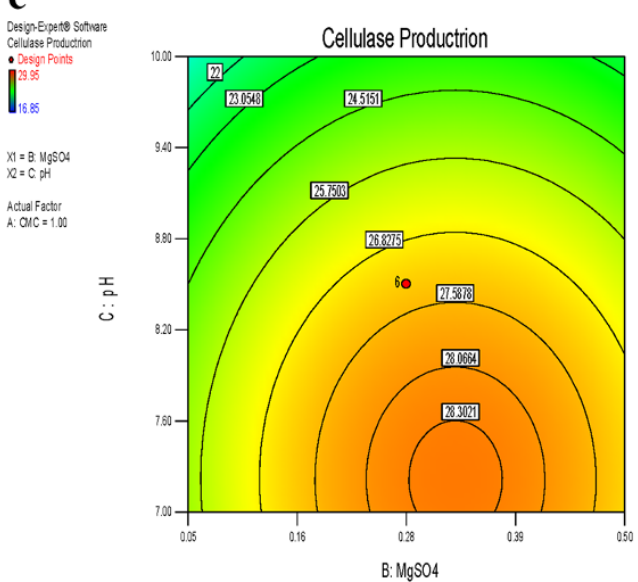

Desing Expete Scthar

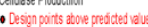

- Design ponts a bovie preadtes lave

$\prod_{18.85}^{2.95}$

$X_{1}=A \cdot A M C$
$X_{2}=B \cdot 1 C_{9} 504$

Actual Factor
$C$ C. HH $=8.50$
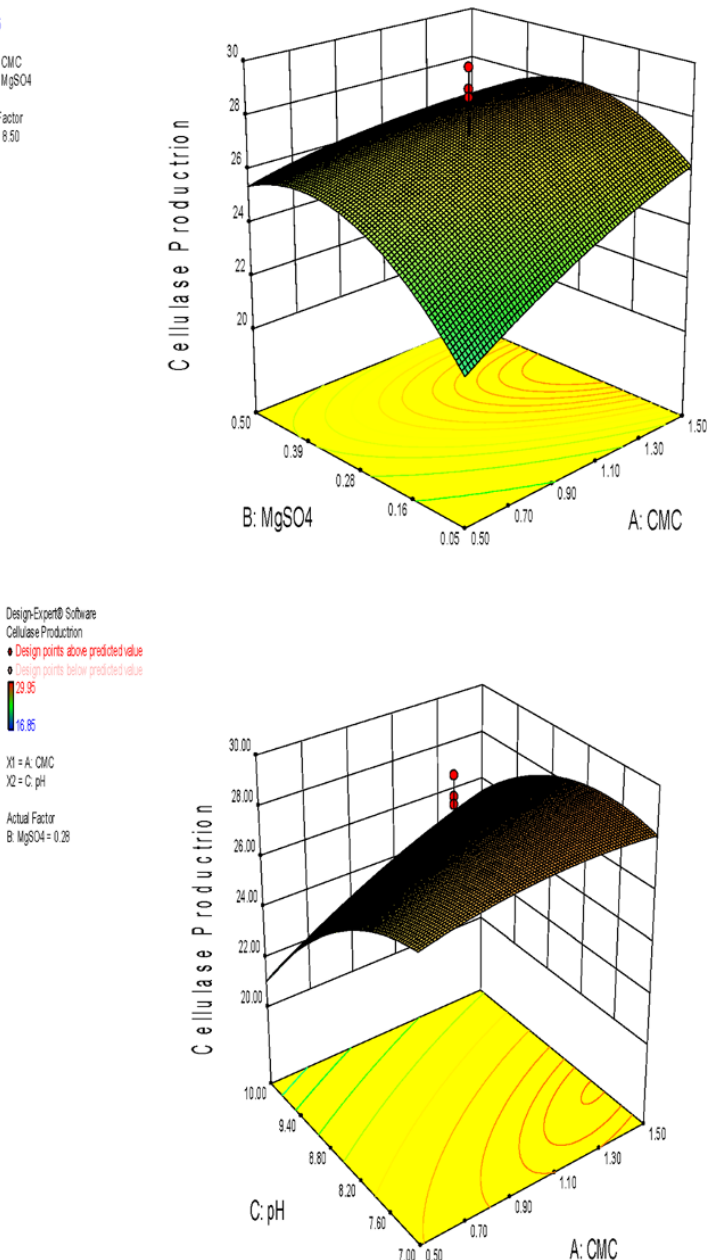

Designexpente Sotviner

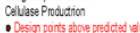

$\prod_{10.6}^{20.50}$

$x=B \quad M_{9 S O S}$
$x=C$ P PH

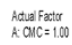

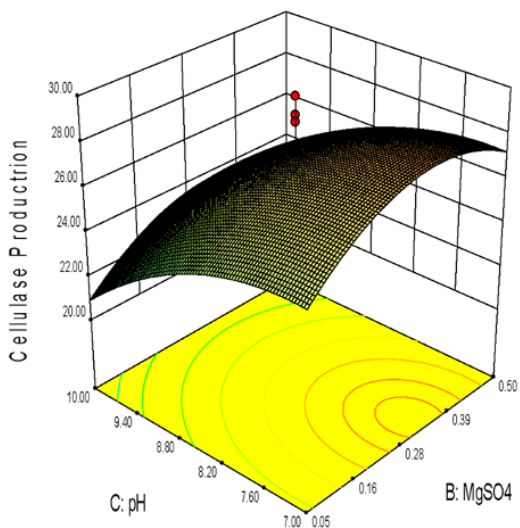

Fig. 2 Response surface graph showing interaction effects between concentration of a $\mathrm{CMC}$ and $\mathrm{MgSO} 4$. b pH and $\mathrm{CMC}$. $\mathbf{c m g S O}$ and $\mathrm{pH}$

in nature) can be used for various applications. The optimum formula of cellulase production from marine isolate Streptomyces ruber was $\mathrm{KH}_{2} \mathrm{PO}_{4} 1.5(\mathrm{~g} / \mathrm{L}), \mathrm{MgSO}_{4} 0.1(\mathrm{~g} / \mathrm{L})$,
$\mathrm{MnSO}_{4} \quad 0.05(\mathrm{~g} / \mathrm{L}), \mathrm{NH}_{4} \mathrm{NO}_{3} \quad 0.5(\mathrm{~g} / \mathrm{L}), \mathrm{NaCl} 1.5(\mathrm{~g} / \mathrm{L})$ with inoculum size of $0.5 \mathrm{~mL}$ [28]. RSM based on CCD was also used to optimize the media for cellulase production using four 
Fig. 3 Genomic DNA of MBAA3

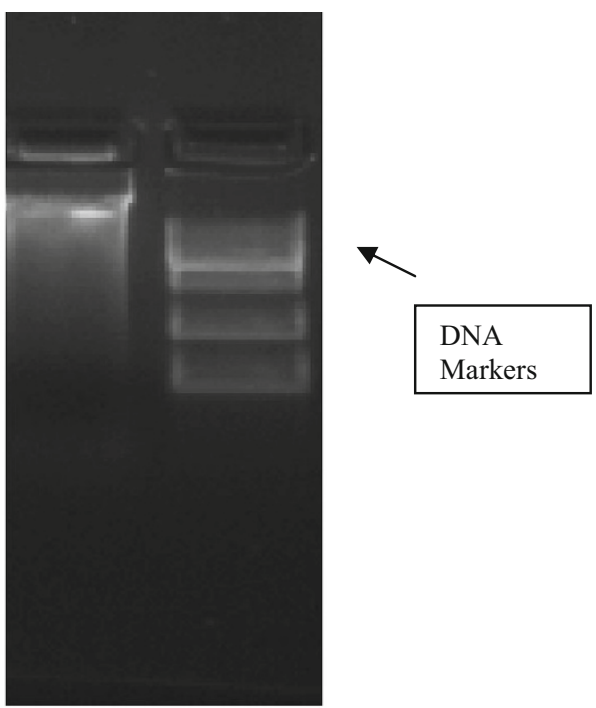

medium constituents, OPEFB fibers $(5-15 \mathrm{~g} / \mathrm{L})$, yeast extract (3-9 g/L), $\mathrm{CaCl} 2(1-5 \mathrm{mM}), \mathrm{MgSO} 4(3-7 \mathrm{mM})$ and to optimize the level of two environmental condition agitation speed (200-300 rpm) and temperature $\left(28-32{ }^{\circ} \mathrm{C}\right)$ from Aspergillus terreus [29]. The production of endoglucanase was studied by Aspergillus terreus by applying the Plackett-Burman design for optimization of process parameters and this study agreed with our results in that, both $\mathrm{KH}_{2} \mathrm{SO}_{4}$ and $\mathrm{MgSO}_{4}$ positively affected CMCase production. High levels of $\mathrm{KH}_{2} \mathrm{SO}_{4}$ and low levels of $\mathrm{MgSO}_{4}$, maximized the enzyme production [30].

\subsection{Validation of the Model}

Validation was carried out under conditions predicted by the model. The optimal concentrations estimated for each variable were $1.84 \mathrm{~g} \mathrm{CMC}^{0} 0.275 \mathrm{~g} \mathrm{MgSO}_{4}$ and $\mathrm{pH}$ 8.5. The predicted cellulase production obtained from the model using the above optimum concentration of medium components was $29.95 \mathrm{U} / \mathrm{mL}$. To validate the prediction of the model, additional experiments in triplicate were performed with the optimized medium. These experiments yielded the maximum cellulase activity of $30.62 \mathrm{U} / \mathrm{mL}$. Agreements between the predicted and experimental results verified the validity of the model and the existence of the optimal points.

The data obtained after optimization has resulted in $29.95 \mathrm{U} / \mathrm{mL}$ enzyme production. After optimization cellulase activity increased by 6.81 fold. The statistical design of experiment offer efficient methodology to identify the significant variables and to optimize the factors with minimum number of experiments for cellulase production by microorganism. These significant factors identified by Plackett-Burman design were considered for the next stage in the medium optimization by using response surface optimization technique. The conversion of cellulosic biomass by microorganisms is a potential sustainable approach to develop novel bioprocesses and products.

\subsection{Isolation and Quantification of Genomic DNA}

For the cellulase gene detection the genomic DNA of MBAA3 was isolated [31] and concentration was $0.498 \mathrm{mg} / \mathrm{mL}$ was confirmed by gel electrophoresis shown in Fig. 3.

\subsection{PCR Amplification of Cellulase Genes}

Amplification of cellulase gene among several sets of primers tried during the study, the best amplification was observed by the primer set CelF This CelF: $5^{\prime}$-ATGAAACG GTCAATCTC-3' and CelR 5'-CTAATTTGGTTCTGTTC CC- $3^{\prime}$ set of primer was tried following the sequence of cellulase gene from B. amyloliquefaciens PSM 3.1 [32]. Among rest of sets of primers, sufficient amplification of cellulase gene could not be achieved as some set of primers showed non specific amplification of gene while a few others amplified DNA fragments of very minute base pair size $(\sim 300)$. The amplification of $1500 \mathrm{bp}$ gene of cellulase by primer set CelF \& CelR is shown in Fig. 4.

Cellulase gene detection screening showed that $\mathrm{Cel}$ genes was present in the MBAA3 and PCR products were sequenced and analyzed using the National center of biotechnological information nBlast database. The PCR product showed very high homology to the nearest sequence of the respective gene. Moreover, a protein BLAST search indicated that this gene show similarity to protein sequence of cellulase. The nucleotide sequence of cellulase gene was submitted in the gene bank under the accession number KF929416. 
Fig. 4 Amplification of cellulases gene from MBAA3. Lane I: amplified cellulase gene using CelF \& CelR primers Lane II: DNA marker at annealing temperature of $58{ }^{\circ} \mathrm{C}$

\begin{tabular}{l}
\hline $\begin{array}{l}1500 \mathrm{bp} \\
\text { cellulase } \\
\text { gene }\end{array}$ \\
\hline
\end{tabular}

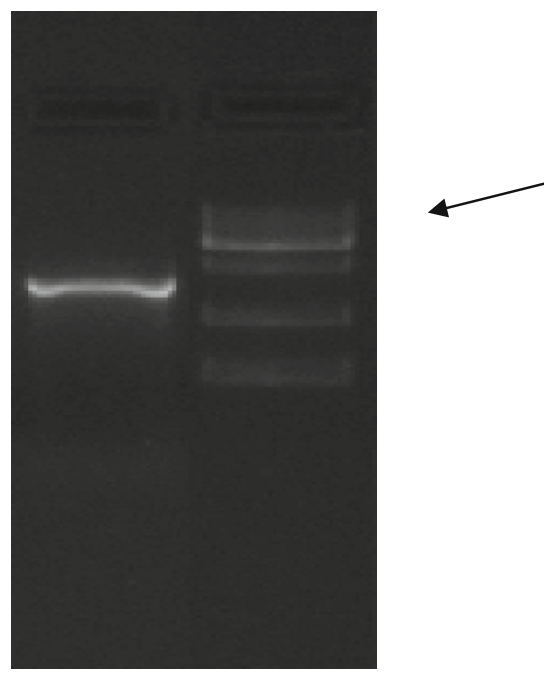

Protein markers
The PCR products obtained using B. amyloliquefaciens PSM 3.1 chromosomal DNA as template were about $1500 \mathrm{bp}$ and other non-specific bands were obtained [32]. Amplification of cellulase gene was reported in which sequence specific primers for cellulase genes were used and significant amplification was achieved from the cDNA and the corresponding bands were found in the gel [33]. The results of this study may further be exploited for characterization of a recombinant cellulase enzyme after its expression in a suitable host to produce novel cellulases with high efficiency. The biological aspects of processing of cellulosic biomass become the crux of future research involving cellulases and cellulolytic microorganisms. With modern biotechnology tools, especially in the area of microbial genetics, novel enzymes and new enzyme applications will become available for the various industries.

\section{Experimental Section}

\subsection{Strain Isolation and Identification}

Bacterial culture isolated from farm soil samples collected from Ahmedabad, Gujarat, India on nutrient agar (Himedia, Mumbai, India) was screened for cellulase production on $\mathrm{CMC}$ agar plate. The screening was done by streaking the isolated colonies on the plates containing $1 \% \mathrm{CMC}$. After $24 \mathrm{~h}$ incubation the plates were flooded with $0.1 \%$ congo red solution and left undisturbed for $15 \mathrm{~min}$. To visualize clear zones formed by cellulase positive strains the plates were destained using $1 \mathrm{M} \mathrm{NaCl}$ solution [34]. Positive and better zone producing strain was chosen and continued for further studies. Culture was maintained at $4{ }^{\circ} \mathrm{C}$ N.agar (peptone $5 \mathrm{~g} / \mathrm{L}, \mathrm{NaCl} 5 \mathrm{~g} / \mathrm{L}$, beef extract $1.5 \mathrm{~g} / \mathrm{L}$, yeast extract $1.5 \mathrm{~g} / \mathrm{L}$, agar $15 \mathrm{~g} / \mathrm{L}, \mathrm{pH}$ 7.4) slants containing $1 \%$
CMC. Genomic DNA of the isolate was extracted and the 16S rDNA gene was amplified using universal primers. The purified PCR product was sequenced and the phylogenic relationship of the isolate was determine by comparing the sequence data with the existing sequences available through the gene bank database of the National Center for Biotechnology Information (NCBI, Bethesda, MD, USA) and the sequence was submitted in the gene bank.

\subsection{Plackett- Burman Experimental Design}

In the first step of the optimization process Plackett-Burman experimental design was used to identify the significance of the ingredients of the media for the optimum production of cellulase enzyme. Plackett-Burman statistical experimental design is very useful and widely employed in the screening of major constituents of the media [35]. This design gave an output of 12 experimental runs with eight independent variables (Table 1). All the experiments were performed in triplicate and the average of cellulase activity was used as the response (dependant variable) [36]. The main effect of each variable was calculated as the difference between the average of measurements made at the high value (+) and at the low value (-) (Table 2). This model does not describe the interaction among the factors and it is used to evaluate and select the important factors that influence the response. The effects of individual parameters on cellulase production were calculated by the following equation:

$\mathrm{E}(\mathrm{Xi})=2(\mathrm{M}+\mathrm{M}-) / \mathrm{N}$

where, $\mathrm{E}$ is the effect of parameter under study; $\mathrm{M}+$ and $\mathrm{M}-$ are responses (cellulase) of trials at which the parameter was at its higher and lower levels, respectively; $\mathrm{N}$ is the total number of trials. 
Table 3 Experimental range and levels of the independent variables of selected components used for response surface central composite design

\begin{tabular}{lllllll}
\hline Variable & Components & $-\alpha$ & -1 & 0 & +1 & $+\alpha$ \\
\hline $\mathrm{A}$ & $\mathrm{CMC}_{\mathrm{BSO}}$ & 0.159104 & 0.5 & 1.0 & 1.5 & 1.840896 \\
$\mathrm{~B}$ & $\mathrm{MgSO}_{4}$ & -0.1034 & 0.05 & 0.275 & 0.5 & 0.653403 \\
$\mathrm{C}$ & $\mathrm{pH}$ & 5.977311 & 7 & 8.5 & 10 & 11.02269 \\
\hline
\end{tabular}

Experimental error was estimated by calculating the variance among the dummy variables as

Veff $=\Sigma(\mathrm{Ed}) 2 / \mathrm{n}$

where, Veff is the variance of the effect of level; Ed is the effect of level for the dummy variables; and $\mathrm{n}$ is the number of dummy variables used in the experiment. The standard error (SE, Es) of concentration effect was the square root of variance of an effect, and the significance level ( $\mathrm{p}$-value) of each concentration effect was determined using the student's t-test:

$\mathrm{t}(\mathrm{Xi})=\mathrm{E}(\mathrm{Xi}) / \mathrm{Es}$

where, $\mathrm{E}(\mathrm{Xi})$ is the effect of variable $\mathrm{Xi}$.

\subsection{Response Surface Methodology (RSM)}

The next step in formulation of the medium was to determine the optimum levels of significant variables for enhancing cellulase production [37]. For this purpose, RSM using CCD was employed. CCD consisting of 20 experimental runs, with 5 axial points $(\alpha \pm 2)$ and 3 replications at the central point (0), was employed to optimize the concentration of significant factors. The design space consisted of three variables, which are $\mathrm{CMC}, \mathrm{MgSO}_{4}$ and $\mathrm{pH}$ as they showed significant positive effect on cellulase production during analysis of PlackettBurman statistical design. RSM is useful for small number of variables (up to 5) but is impractical for large number of variables, due to high number of experimental runs required. According to the design, the total number of treatment combinations is $2^{\mathrm{k}}+2 \mathrm{k}+\eta_{\mathrm{o}}$, where $\mathrm{k}$ is the number of independent variables and $\eta_{\mathrm{o}}$ is the number of repetition of experiments at the central point. Each factor in the design was studied at five different levels $(-\alpha,-1,0,+1,+\alpha)$ as shown in Table 3. The minimum and maximum ranges of variables were determined on the basis of our previous experiments. The full experimental plan with respect to their values in actual and coded form is listed in Table 6. Enzymatic activity was measured in triplicate in 20 different experimental runs. The cellulase production was analyzed by using a second order polynomial equation, and the data were fitted into the equation by multiple regression procedure. The model equation for analysis is given as:

$Y=\beta 0+\beta i X i+\beta i i X i 2+\beta i j X i X j$

where, $\beta 0, \beta \mathrm{i}, \beta \mathrm{ii}$, and $\beta \mathrm{ij}$ represent the constant process effect in total, the linear, quadratic effect of $\mathrm{Xi}$, and the interaction effect between $\mathrm{Xi}$ and $\mathrm{Xj}$, respectively for the production of cellulase. Later, an experiment was run using the optimum values for variables given by response optimization to confirm the predicted value and cellulase production was confirmed. Flask with $100 \mathrm{~mL}$ of autoclaved production medium inoculated with $1 \mathrm{~mL}$ of culture was incubated in rotary shaker at $200 \mathrm{rpm}$ at $37{ }^{\circ} \mathrm{C}$ for $48 \mathrm{~h}$. The DNS assay was carried out as follows to determine cellulase activity. $0.5 \mathrm{~mL}$ of culture filtrate was mixed with $0.5 \mathrm{~mL} 1 \% \mathrm{CMC}$ in phosphate buffer $\mathrm{pH} 7$ in a test tube and incubated at $40{ }^{\circ} \mathrm{C}$ for $30 \mathrm{~min}$. The reaction was terminated by adding $2 \mathrm{~mL}$ of DNS reagent. The tube was then incubated in boiling waterbath for $15 \mathrm{~min}$ The OD was taken at $540 \mathrm{~nm}$ against blank. One unit of the cellulase activity refers to the amount of enzyme that released $1 \mu \mathrm{g}$ of glucose under assay condition [38].

\subsection{Software and Data Analysis}

The results of the experimental design were analyzed and interpreted using Design-Expert version 8.0 (Stat-Ease Inc., Minneapolis, MN, USA) statistical software.

\subsection{Isolation of DNA for Cellulase Gene Amplification}

For cellulase gene detection the isolate was grown aerobically overnight at $37{ }^{\circ} \mathrm{C}$ in LB broth. Bacterial chromosomal DNA was purified using Genomic DNA Purification Kit (Xcelgen).

\subsection{Quantization and Quality Assessment of DNA}

The DNA stock samples was quantified using nanodrop spectrophotometer at 260 and $280 \mathrm{~nm}$ using the convention that one absorbance unit at $260 \mathrm{~nm}$ wavelength equals $50 \mu \mathrm{g}$ DNA per ml. Purity of DNA was judged on the basis of optical density ratio at 260:280 nm [32]. The DNA having ratio between 1.8 and 2.0 was considered to be of good purity. Concentration of DNA was estimated using the formula.

Concentration of DNA $(\mathrm{mg} / \mathrm{mL})=$ OD $260 \times 50 \times$ Dilution factor.

Quality and purity of DNA were checked by agarose gel electrophoresis. Agarose $0.8 \%(\mathrm{w} / \mathrm{v})$ in $0.5 \mathrm{X}$ TAE $(\mathrm{pH}$ 8.0) buffer was used for submarine gel electrophoresis. 
Table 4 Steps and conditions of thermal cycling for PCR

\begin{tabular}{lllc}
\hline Steps & Temperature & Time & Cycles \\
\hline Initial denaturation & $95{ }^{\circ} \mathrm{C}$ & $2 \mathrm{~min}$ & 1 \\
Final denaturation & $94{ }^{\circ} \mathrm{C}$ & $30 \mathrm{Sec}$ & 30 \\
Annealing & $58{ }^{\circ} \mathrm{C}$ & $30 \mathrm{Sec}$ & \\
Extention & $72{ }^{\circ} \mathrm{C}$ & $90 \mathrm{Sec}$ & \\
Final extention & $72{ }^{\circ} \mathrm{C}$ & $10 \mathrm{~min}$ & 1
\end{tabular}

Ethidium bromide (1\%) was added @ $10 \mu \mathrm{l} / 100 \mathrm{~mL}$. The wells were charged with $5 \mu \mathrm{L}$ of DNA preparations mixed with $1 \mu \mathrm{L}$ gel loading dye. Electrophoresis was carried out at $80 \mathrm{~V}$ for $30 \mathrm{~min}$ at room temperature. DNA was visualized under UV using UV transilluminator. The DNA was used further for amplification of cellulase gene.

\subsection{Polymerase Chain Reaction}

For the confirmation of cellulase gene the gene fragment was amplified by PCR from genomic DNA using gene specific set of primers: celF (5'-ATGAAACGGTCAATC TC- $\left.3^{\prime}\right)$ and celR ( $5^{\prime}$-CTAATTTGGTTCTGTTCCC- $\left.{ }^{\prime}\right)$ [32]. PCR was carried out in a final reaction volume of $25 \mu \mathrm{l}$ in $200 \mu \mathrm{L}$ capacity thin wall PCR tube in Eppendorf Thermal Cycler. Reaction mixture for PCR tubes containing the mixture were tapped gently and spin briefly at $10000 \mathrm{rpm}$. The PCR tubes with all the components were

Table 5 Statistical analysis of components by Plackett-Burman design for cellulase production by Bacillus amyloliquifaciens strain MBAA3

\begin{tabular}{|c|c|c|c|c|c|}
\hline Component & Effect & Standard error & T-value & $P$ Value & Confidence $(\%)$ \\
\hline $\mathrm{CMC}$ & 17.49 & 3.963858 & 4.412368 & 0.0216 & 97.83997 \\
\hline Sucrose & 8.99 & 5.04375 & 1.782404 & 0.1727 & 82.72997 \\
\hline Yeast extract & 2.778333 & 5.04375 & 0.550847 & 0.620106 & 37.98936 \\
\hline peptone & 2.896667 & 5.04375 & 0.574308 & 0.605995 & 39.40054 \\
\hline $\mathrm{K}_{2} \mathrm{HPO}_{4}$ & 0.643333 & 5.04375 & 0.127551 & 0.906574 & 9.342577 \\
\hline $\mathrm{MgSO}_{4}$ & 18.47333 & 5.04375 & 3.662619 & 0.035181 & 96.48193 \\
\hline Temperature & 9.23 & 5.04375 & 1.829988 & 0.164672 & 83.53282 \\
\hline $\mathrm{pH}$ & 16.33333 & 5.04375 & 3.238331 & 0.047912 & 95.20884 \\
\hline
\end{tabular}

Table 6 Full experimental central composite design with coded and actual level of variables and the response function

\begin{tabular}{|c|c|c|c|c|c|c|c|c|}
\hline \multirow[b]{2}{*}{ Run } & \multicolumn{2}{|c|}{ A: $\mathrm{CMC}_{\mathrm{G}} \%$} & \multicolumn{2}{|l|}{ B: $\mathrm{MgSO}_{4}$} & \multicolumn{2}{|l|}{$\mathrm{Ph}$} & \multicolumn{2}{|c|}{ Cellulase activity $\mathrm{U} / \mathrm{mL}$} \\
\hline & Actual & Coded & Actual & Coded & Actual & Coded & Actual & Predicted \\
\hline 1 & 0.5 & -1 & 0.05 & -1 & 7 & -1 & 23.6 & 23.88629 \\
\hline 2 & 1.5 & +1 & 0.05 & -1 & 7 & -1 & 24.55 & 26.20009 \\
\hline 3 & 0.5 & -1 & 0.5 & +1 & 7 & -1 & 25.05 & 27.348 \\
\hline 4 & 1.5 & +1 & 0.5 & +1 & 7 & -1 & 24.85 & 26.23679 \\
\hline 5 & 0.5 & -1 & 0.05 & -1 & 10 & +1 & 16.85 & 17.38949 \\
\hline 6 & 1.5 & +1 & 0.05 & -1 & 10 & +1 & 24 & 23.62829 \\
\hline 7 & 0.5 & -1 & 0.5 & +1 & 10 & +1 & 20.55 & 20.8262 \\
\hline 8 & 1.5 & +1 & 0.5 & +1 & 10 & +1 & 22 & 23.63999 \\
\hline 9 & 0.159104 & $-\alpha$ & 0.275 & 0 & 8.5 & 0 & 25.1 & 24.00702 \\
\hline 10 & 1.840896 & $+\alpha$ & 0.275 & 0 & 8.5 & 0 & 29.95 & 28.3188 \\
\hline 11 & 1 & 0 & -0.1034 & $-\alpha$ & 8.5 & 0 & 20.7 & 20.37752 \\
\hline 12 & 1 & 0 & 0.653403 & $+\alpha$ & 8.5 & 0 & 25.7 & 23.2983 \\
\hline 13 & 1 & 0 & 0.275 & 0 & 5.977311 & $-\alpha$ & 29.8 & 27.3863 \\
\hline 14 & 1 & 0 & 0.275 & 0 & 11.02269 & $+\alpha$ & 20.05 & 19.73953 \\
\hline 15 & 1 & 0 & 0.275 & 0 & 8.5 & 0 & 24.3 & 27.31957 \\
\hline 16 & 1 & 0 & 0.275 & 0 & 8.5 & 0 & 29 & 27.31957 \\
\hline 17 & 1 & 0 & 0.275 & 0 & 8.5 & 0 & 28.7 & 27.31957 \\
\hline 18 & 1 & 0 & 0.275 & 0 & 8.5 & 0 & 24.75 & 27.31957 \\
\hline 19 & 1 & 0 & 0.275 & 0 & 8.5 & 0 & 26.9 & 27.31957 \\
\hline 20 & 1 & 0 & 0.275 & 0 & 8.5 & 0 & 29.8 & 27.31957 \\
\hline
\end{tabular}


Table 7 Analysis of variance of quadratic model for cellulase production using MBAA3

\begin{tabular}{lccccc}
\hline Source & $\begin{array}{l}\text { Sum of } \\
\text { squares }\end{array}$ & df & \multicolumn{1}{l}{$\begin{array}{l}\text { Mean } \\
\text { square }\end{array}$} & $\begin{array}{l}\text { F } \\
\text { value }\end{array}$ & $\begin{array}{l}P \text { value } \\
\text { Prob }>\text { F }\end{array}$ \\
\hline Model & 189.9858 & 9 & 21.10953213 & 3.79448 & 0.0247 \\
A-CMC & 22.4418 & 1 & 22.44179898 & 4.033958 & 0.0724 \\
$\mathrm{~B}-M g S O_{4}$ & 10.29776 & 1 & 10.29776171 & 1.851043 & 0.2035 \\
$\mathrm{C}-\mathrm{pH}$ & 70.58331 & 1 & 70.58331317 & 12.68749 & 0.0052 \\
$\mathrm{AB}$ & 5.865313 & 1 & 5.8653125 & 1.054302 & 0.3287 \\
$\mathrm{AC}$ & 7.702812 & 1 & 7.7028125 & 1.384596 & 0.2666 \\
$\mathrm{BC}$ & 0.000312 & 1 & 0.0003125 & $5.62 \mathrm{E}-05$ & 0.9942 \\
$\mathrm{~A}^{\wedge} 2$ & 2.410015 & 1 & 2.410015225 & 0.433205 & 0.5253 \\
$\mathrm{~B}^{\wedge} 2$ & 54.12976 & 1 & 54.1297625 & 9.729932 & 0.0109 \\
$\mathrm{C}^{\wedge} 2$ & 25.42233 & 1 & 25.42232541 & 4.569713 & 0.0583 \\
Residual & 55.63221 & 10 & 5.56322108 & & 0.4672 \\
Lack of fit & 28.89013 & 5 & 5.778025493 & 1.080324 & Not significant \\
Pure error & 26.74208 & 5 & 5.348416667 & & \\
Core total & 245.618 & 19 & & & \\
\hline
\end{tabular}

transferred to thermal cycler. The PCR protocol designed for 30 cycles for the primers used is given in Table 4.

\subsection{Visualization and Purification of PCR Product}

To confirm the targeted PCR amplification, $5 \mu \mathrm{L}$ of PCR product from each tube was mixed with $1 \mu \mathrm{L}$ of $6 \times$ gel loading dye and electrophoresed on $1.2 \%$ agarose gel containing ethidium bromide (1 per cent solution @ $10 \mu \mathrm{L} /$ $100 \mathrm{~mL}$ ) at constant $5 \mathrm{~V} / \mathrm{cm}$ for $30 \mathrm{~min}$ in $0.5 \times \mathrm{TAE}$ buffer. The amplified product was visualized as a single compact band of expected size under UV light and documented by gel documentation system (Biorad). Length of the product is approx.1500 bp Amplified PCR product was purified using Qiagen Mini elute Gel extraction kit according to the manufactures protocol.

\subsection{Sequencing of Purified Gene Segment}

The concentration of the purified DNA was determined and was subjected to automated DNA sequencing on ABI 3730xl Genetic Analyzer (Applied Biosystems, USA). Sequencing was carried out using BigDye ${ }^{\circledR}$ Terminator v3.1 Cycle sequencing kit following manufacturer instructions. Cycle sequencing was performed following the instructions supplied along with BigDye ${ }^{\circledR}$ Terminator v3.1 Cycle Sequencing Kit. The reaction was carried out in a final reaction volume of $20 \mu \mathrm{L}$ using $200 \mu \mathrm{L}$ capacity thin wall PCR tube. The cycling protocol was designed for 25 cycles Denaturation at $96{ }^{\circ} \mathrm{C}$ for $10 \mathrm{~s}$, Annealing at $58{ }^{\circ} \mathrm{C}$ for $5 \mathrm{~s}$ and Extension at $60{ }^{\circ} \mathrm{C}$ for $4 \mathrm{~min}$ with the thermal ramp rate of $1{ }^{\circ} \mathrm{C}$ per second. After cycling, the extension products were purified and mixed well in $10 \mu \mathrm{L}$ of Hi-Di formamide. The contents were mixed on shaker for $30 \mathrm{~min}$ at $300 \times \mathrm{g}$. Eluted PCR products were placed in a sample plate and covered with the septa. Sample plate was heated at $95{ }^{\circ} \mathrm{C}$ for $5 \mathrm{~min}$, snap chilled and loaded into autosampler of the instrument.

Electrophoresis and data analysis was carried out on the ABI 3730xl Genetic Analyzer using appropriate Module, Basecaller, Dyeset/Primer and Matrix files.

Acknowledgments We are thankful to Department of Microbiology, University School of Sciences, Gujarat University, Ahmedabad, for providing necessary facilities.

Conflict of Interest Authors declare that there no conflict of interest to publish this manuscript.

Open Access This article is distributed under the terms of the Creative Commons Attribution License which permits any use, distribution, and reproduction in any medium, provided the original author(s) and the source are credited.

\section{References}

1. R.C. Kuhad, R. Gupta, A. Singh, Enz. Res. 2011, 1-10 (2011)

2. Y.H.P. Zhang, L.R. Lynd, Biotech. Bioeng. 88, 797-824 (2004)

3. L.R. Lynd, P.J. Weimer, W.H. van Zyl, I.S. Pretorius, Microbiol. Mol. Biol. Rev. 66, 506-577 (2002)

4. S. Sethi, A. Datta, B.L. Gupta, S. Gupta, ISRN Biotechnol. 2013, 1-7 (2013)

5. L.R. Lynd, W.H. Van Zyl, J.E. Mcbride, M. Laser, Curr. Opin. Biotechnol. 16, 577-583 (2005)

6. A. M. Abdel-Mawgoud, M. M. Aboulwafa, H. N. Abdel-Haleem, Appl. Biochem. Biotechnol. 150, 305-325 (2008)

7. S.B. Riswan ali, R. Muthuvelayudham, T. Viruthagiri, Innov. Rom. Food Biotechnol. 12, 40-51 (2013)

8. B.J. Naveena, M.D. Altaf, K. Bhadriah, G. Reddy, Bioresour. Technol. 96, 485-490 (2005) 
9. S. Puri, Q.K. Beg, R. Gupta, Curr. Microbiol. 44, 286-290 (2002)

10. T. Shankar, L. Isaiarasu, Global J. Biotechnol. Biochem. 7, 1-6 (2012)

11. R.S. Karthikeyan, S.K. Rakshit, A. Baradarajan, Bioproc. Eng. 15, 247-251 (1996)

12. A. Ahamed, P. Vermette, Biochem. Eng. J. 40, 399-407 (2008)

13. Y. Li, J. Lin, D.J. Meng, J. Lu, G.X. Gu, Z.G. Mao, Food Technol. Biotechnol. 44, 473-477 (2006)

14. F. Cui, L. Zhao, Int. J. Mol. Sci. 13, 10630-10646 (2012)

15. B.J. Naveena, M.D. Altaf, K. Bhadrayya, S.S. Madhavendra, G. Reddy, Food Technol. Biotechnol. 42, 147-152 (2004)

16. B.N. Gawande, A.Y. Patkar, Biotechnol. Bioeng. 64, 168-172 (1999)

17. M.K. Mahat, R.M. Illias, R.A. Rahman, N.A.A. Rashid, O. Hassan, Enz. Microbiol. Tech. 35, 467-473 (2004)

18. V. Gohel, D. Jiwan, P. Vyas, H.S. Chatpar, J. Microbiol. Biotechnol. 15, 197-201 (2005)

19. J.L.U.M. Rao, T. Satyanarayana, J. Appl. Microbiol. 95(4), 712-718 (2003)

20. S.R. Nair, T. Panda, Bioproc. Biosyst. Eng. 16(3), 169-173 (1997)

21. M.S.R.C. Murthy, T. Swaminathan, S.K. Rakshit, Y. Kosugi, Bioproc. Biosyst. Eng. 22, 35-39 (2000)

22. V. Pujari, T.S. Chandra, Process Biochem. 36, 31-37 (2000)

23. S.N.A. Azaman, N.R. Ramakrishnan, J.S. Tan, R.A. Rahim, M.P. Abdullah, A.B. Ariff, Biotechnol. Appl. Biochem. 56, 141-150 (2010)

24. S. Nagar, V.K. Gupta, D. Kumar, L. Kumar, R.C. Kuhad, J. Ind. Microbiol. Biotechnol. 37, 71-83 (2010)
25. P. Mishra, P.R. Kshirsagar, S.S. Nilegaonkar, S.K. Sing, J. Basic Microbiol. 52, 539-548 (2012)

26. W. Li, W. Zhang, M.M. Yang, Y.L. Chen, Mol. Biotechnol. 40, 195-201 (2008)

27. A. Rastogi, A. Bhalla, A. Adhikari, K.M. Bischoff, H.R. Hughes, L.P. Christopher, R.K. Sani, Bioresour. Technol. 101, 8798-8806 (2010)

28. N.A. El-Sersy, H.A.H. Ibrahim, G.M. Abou-Elela, Curr. Res. Bacteriol. 3, 1-14 (2010)

29. M.S. Nour, M.N.A. Wahab, A. Ariff, R. Mohamad, Aust. J. Basic Appl. Sci. 12, 6106-6124 (2010)

30. G.A. Youssef, M.M. Berekaa, Biotechnology 8, 212-219 (2009)

31. Y.M. Yamada, M. Koiche, O. Hossan, N. Kumito, Y. Yayoi, O. Masako, Jpn. J. Infect. Dis. 55, 122-125 (2002)

32. Z. Nurachman, S.D. Kurniasih, F. Puspitawati, S. Hadi, O.K. Radjasa, D. Natalia, Am. J. Biochem. Biotechnol. 6, 268-274 (2010)

33. S. Ahmed, N. Aslam, F. Latif, M.I. Rajoka, A. Jamil, Front. Nat. Prod. Chem. 1, 73-75 (2005)

34. S. Bai, M. Ravi kumar, D.J. Mukesh kumar, P. Balashanmugam, M.D. Bala kumaran, P.T. Kalaichelvan, Archiv. Appl. Sci. Res. 4, 269-279 (2012)

35. R.L. Placket, J.P. Burman, Biometrika 33, 305-325 (1944)

36. Y. Singh, S.K. Shrivastava, Ind. J. exp. Bol. 51, 322-335 (2013)

37. V.S. Prajapati, U.B. Trivedi, K.C. Patel, Food Sci. Biotechnol. 22, 31-38 (2013)

38. L.J. Yin, H.H. Lin, Z.R. Xiao, J. Marine Sci. Technol. 18, 466-471 (2010) 